\title{
Publikacje polskich naukowców indeksowane w Social Sciences Citation Index w latach 2009-2015
}

STRESZCZENIE. W artykule przeanalizowano publikacje polskich naukowców indeksowane w Social Sciences Citation Index. Wzięto pod uwagę wszystkie artykuły oraz artykuły przeglądowe z lat 20092015 ( $N=6109$ ) opublikowane w 1799 czasopismach. Każdemu czasopismu przyporządkowany został odpowiedni kwartyl Impact Factora na podstawie danych z Journal Citation Reports. Badanie pokazało, że polscy naukowcy publikują coraz więcej artykułów w czasopismach z części A „Wykazu czasopism punktowanych” i jednocześnie coraz częściej wybierają czasopisma z I lub II kwartyla Impact Factora.

SŁOWA KLUCZOWE: Social Sciences Citation Index, Journal Citation Report, kwartyl Impact Factor, ocena parametryczna

\section{Wstęp}

Publikowanie wyników badań w prestiżowych międzynarodowych czasopismach jest ważnym elementem polityki naukowej wyznaczanej przez Ministerstwo Nauki i Szkolnictwa Wyższego, a także przez uczelnie czy poszczególne jednostki naukowe, dla których stanowi ono istotny element oceny (Kulczycki, Rozkosz i Drabek 2016; Kulczycki, Drabek i Rozkosz 2015). Także badacze wiedzą, jak cenny jest międzynarodowy dorobek publikacyjny nie tylko dla jednostek, ale przede wszystkim dla nich samych: w postępowaniach awansowych czy przy ubieganiu się o granty.

W stosowanej w Polsce od blisko 20 lat parametrycznej ocenie jednostek naukowych bardzo ważną rolę odgrywają artykuły opublikowane w czasopismach indeksowanych w bazie Web of Science Core Collection, a szczególnie w tych periodykach, dla których rokrocznie wyliczany jest najpopularniejszy wskaźnik oceny czasopism na świecie - Impact Factor (IF). Wskaźnik ten - opracowany przez 
Eugene'a Garfielda jako pomoc w selekcji czasopism do tworzonych przez niego indeksów cytowań (Garfield 2006) - niespodziewanie stał się jedną z najczęściej stosowanych miar oceny badaczy czy instytucji naukowych. Wyliczenie, a następnie przypisanie IF konkretnemu czasopismu automatycznie nobilituje wszystkie opublikowane w nim artykuły, a autorzy skrzętnie odnotowują ten fakt w swoim dorobku. Choć w świecie nauki wciąż pojawiają się analizy, z których wynika, że wykorzystywanie IF do oceny poszczególnych osób jest nieuzasadnione, a także głosy nawołujące do rezygnacji z ewaluacji opartej na IF (Towpik 2015), popularność tego wskaźnika wydaje się nie słabnąć.

W tworzonych w Polsce „Wykazach czasopism punktowanych” także wykorzystuje się Impact Factor do tworzenia części A, w której znajdują się najwyżej punktowane międzynarodowe czasopisma naukowe z nauk społecznych i ścisłych. Od 2012 r. autor pracy afiliowanej w danej jednostce może jej przynieść nawet 50 punktów za pojedynczy artykuł (zakres punktowy czasopism z tej części „Wykazu” wynosi 15-50 punktów). Natomiast monografia może przynieść autorowi 25 punktów, a w nielicznych przypadkach, gdy spełnia wymogi bycia wybitną ${ }^{1}-50$ punktów. Nic więc dziwnego, że celem autorów staje się publikacja badań w czasopismach wymienionych w części A „Wykazu”. Działania uczelni także zmierzają w kierunku motywowania pracowników do przesyłania wyników swoich prac właśnie do tych czasopism. W dodatku nie tylko do tych z najmniejszą liczbą punktów (15), ale przede wszystkim do tych wyżej punktowanych ${ }^{2}$.

Zagadnienia dotyczące systemu oceny jakości jednostek naukowych i czuwania nad jakością pojawiły się w założeniach wszystkich trzech projektów ustawy o szkolnictwie wyższym (tzw. Ustawy 2.0) (Kwiek 2016; Izdebski 2017; Radwan 2017). Jednakże zespół pod kierownictwem dr. hab. Arkadiusza Radwana w podrozdziale dotyczącym wad i ograniczeń istniejących rozwiązań w zakresie zapewnienia jakości zwrócił uwagę, że istniejący system oceny parametrycznej przyczynia się do powstania negatywnego zjawiska - punktozy, czyli „produkowania osiągnięć w celu zgromadzenia jak największej liczby punktów” (Radwan 2017: 203). Dalej

${ }^{1}$ Zgodnie z Rozporządzeniem MNiSW z 12 grudnia 2016 r. (Dz.U. z 27.12.2016 r., poz. 2154) w sprawie przyznawania kategorii naukowej jednostkom naukowym i uczelniom, w których zgodnie z ich statutami nie wyodrębniono podstawowych jednostek organizacyjnych.

${ }^{2}$ Przykładem takich działań jest regulacja stosowana w Szkole Głównej Handlowej, na mocy której nauczyciel akademicki może ubiegać się o grant, jeśli opublikuje artykuł w czasopiśmie z listy Journal Citation Reports (JCR) (Zarządzenie 2016, § 2, pkt 2). Od 2013 r. w Instytucie Psychologii Katolickiego Uniwersytetu Lubelskiego przyznawana jest Nagroda im. prof. Josepha B. Sidowskiego za publikacje w czasopismach z Journal Citation Reports (Regulamin 2014). Innym przykładem finansowej motywacji za publikacje w czasopismach z JCR są rozwiązania opisane w Regulaminie w sprawie zasad, trybu i kryteriów kwalifikacyjnych przyznawania nagród Rektora nauczycielom akademickim Uniwersytetu Medycznego w Białymstoku, który podaje nawet konkretną kwotę nagrody w zależności od liczby punktów przyznanych za pojedynczy artykuł (musi ich być więcej niż 20) (Regulamin 2016). 
w tym samym dokumencie możemy przeczytać, że ,jednym z efektów [oceny parametrycznej - A.D.] jest lawinowo rosnąca liczba publikacji w postaci artykułów naukowych, szczególnie w czasopismach z wyliczonym wskaźnikiem IF z trzeciej i czwartej ćwiartki rozkładu punktowego (malejąco)" (Radwan 2017: 204). W niniejszym tekście nie będę się odnosić do zjawiska punktozy, ponieważ kwestia ta była już przedmiotem rozważań (Kulczycki 2017a; 2017b; Zabel i in. 2014). Skupię się natomiast na zasadności postawionego przez zespół Radwana twierdzenia, że polscy autorzy, wybierając jako miejsce publikacji czasopisma z części A „Wykazu czasopism punktowanych", poprzestają głównie na słabszych periodykach, zlokalizowanych w dolnych częściach rankingu opartego na wskaźniku Impact Factor („trzecia i czwarta ćwiartka rozkładu punktowego”).

Celem tego artykułu jest zbadanie, jak wygląda dorobek polskich naukowców opublikowany w czasopismach indeksowanych w Social Sciences Citation Index (SSCI) (część bazy Web of Science Core Collection) w latach 2009-2015. Jako znormalizowaną miarę oceny wybrałam kwartyl IF, do którego przyporządkowane zostało czasopismo. O wykorzystaniu tego typu miary pisał Let Leydesdorff (2012), wskazując, że może być ona użyteczną alternatywą dla IF. Podobną metodą posłużyły się Aline Solari i Marie-Helene Magri (2000), które podzieliły czasopisma na pięć grup.

Dane o kwartylach pochodzą z bazy Journal Citation Reports i wyliczane są osobno dla każdej dyscypliny po uszeregowaniu czasopism według malejącej wartości wskaźnika IF w danym roku. W I kwartylu mieści się 25\% czasopism z najwyższą wartością w danym roku; w II kwartylu - kolejne 25\%, natomiast w III i IV kwartylu - pozostałe 50\% czasopism.

Przeprowadzone badanie pozwoli odpowiedzieć na następujące pytania:

- Czy polscy badacze publikują coraz więcej tekstów w czasopismach indeksowanych w SSCI?

- Czy rośnie liczba artykułów opublikowanych w czasopismach z III i IV kwartyla?

- Czy rośnie liczba publikacji z zakresu nauk społecznych w polskich czasopismach z części A „Wykazu”?

\section{1.Źródło danych}

W przeprowadzonym badaniu wykorzystałam bazę Social Sciences Citation Index, która jest jednym z ośmiu indeksów cytowań składających się na Web of Science Core Collection. Dla czasopism indeksowanych w SSCI oraz Science Citation Index Expanded co rok wyliczany jest wskaźnik IF, który następnie publikowany jest w innej bazie danych, tj. Journal Citation Reports. Dodać należy, że w bazie SSCI indeksowane są czasopisma z nauk społecznych (ok. 3200 tytułów), ale także te 
artykuły opublikowane w czasopismach z nauk ścisłych, których tematyka dotyczy jednej z dyscyplin z nauk społecznych.

Pierwszy etap pozyskiwania danych polegał na wyszukaniu rekordów spełniających następujące warunki:

- rekord pochodził z bazy SSCI,

- co najmniej jeden z autorów jako afiliację podał instytucję polską (pole Address = Poland),

- tekst został opublikowany w latach 2009-2015 (pole Years = 2009-2015),

- typ publikacji to article bądź review.

Następnie wyodrębniłam listę 1799 czasopism, w których znalazła się co najmniej jedna praca z polską afiliacją opublikowana w badanym okresie. W drugim etapie wszystkie te czasopisma zostały sprawdzone w Journal Citation Reports i dla każdego czasopisma przyporządkowałam odpowiedni kwartyl IF. W sytuacji gdy periodyk przynależał do kilku dyscyplin, wybierałam wariant najkorzystniejszy, np. kwartyl III zamiast IV. Na koniec każdy rekord artykułu został powiązany z danymi o kwartylu IF czasopisma, w którym został opublikowany.

\section{Wyniki}

Baza SSCI zawiera 8533 publikacje polskich autorów wydane w latach 2009-2015, w tym 6354 artykuły (article), 202 artykuły przeglądowe (review) oraz 1977 innych rodzajów publikacji (np. abstrakty, wstępy, recenzje, listy, korekty i inne). Całościowo w dalszej analizie uwzględniłam 6556 publikacji (artykuły i artykuły przeglądowe), pomijając inne typy publikacji. Nie do wszystkich odnalezionych publikacji udało się przyporządkować właściwy kwartyl, ponieważ część czasopism nie miała w niektórych latach wyliczonego wskaźnika IF. Przyczyny mogą być dwie: albo czasopismo było w początkowym okresie indeksowania w SSCI (pierwszy IF wylicza się dopiero w trzecim roku funkcjonowania danego periodyku w bazie), albo wydawca bazy w danym roku zrezygnował z wyliczania IF z powodu nieetycznych zachowań (np. nadmiernego autocytowania). W latach 2009-2015 artykułów takich było 447, z tego najwięcej z 2009 r. (151 pozycji) i 2012 r. (137), a najmniej z lat 2014-2015 (odpowiednio: 17 i 8 pozycji). Ponieważ rekordy bez dopasowanego kwartyla nie nadawały się do dalszego badania, zostały wyłączone ze zbioru. W związku z tym pozostało 6109 publikacji, które stały się podstawą poniższych analiz.

W badanym okresie można zauważyć stały wzrost liczby tekstów z nauk społecznych. Liczba artykułów z 2015 r. jest ponad trzyipółkrotnie większa (1410 tekstów) od tej z 2009 r. (403 teksty). Warto dodać, że w latach 2008-2009 baza SSCI znacznie się rozszerzyła i w porównaniu z $2007 \mathrm{r}$. liczba indeksowanych czasopism wzrosła o ponad 35\%. W $2008 \mathrm{r}$. włączono do SSCI sześć polskich czasopism z nauk społecznych, powiększając tym samym listę polskich periodyków do dziewięciu. 
Poszerzenie SSCI na pewno miało wpływ na liczbę publikacji w polskich czasopismach oraz na liczbę polskich prac w ogóle. Wykres 1 prezentuje dane dotyczące liczby artykułów z polską afiliacją w poszczególnych latach.

Wykres 1. Liczba publikacji polskich autorów w bazie SSCI w latach 2009-2015

$$
(N=6556)
$$

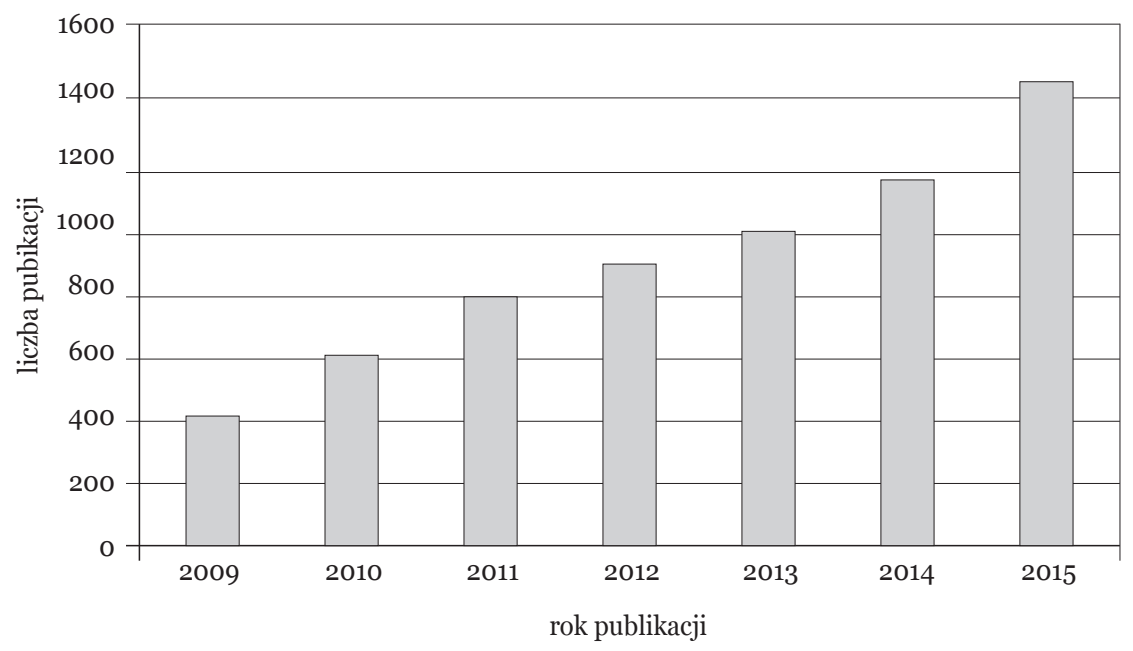

Źródło: opracowanie własne.

Z powyższego wykresu możemy się dowiedzieć zaledwie, że polscy autorzy z roku na rok publikowali coraz więcej prac w czasopismach z części A „Wykazu czasopism punktowanych" z zakresu nauk społecznych, co stanowi odpowiedź na pierwsze z postawionych w tym tekście pytań badawczych. Ważne było jednak sprawdzenie, czy poprzestają oni na periodykach z najniższymi wartościami IF (III i IV kwartyl), czy też wybierają te z górnych miejsc rankingu opartego na wskaźniku Impact Factor.

Porównanie danych z podziałem na poszczególne kwartyle IF pokazało, że liczba publikacji z czasopism z IV kwartyla od 2010 r. maleje (z niewielkim wzrostem w 2015 r.), liczba publikacji z III kwartyla od 2012 r. pozostaje na stałym poziomie ok. 20\% polskich prac w SSCI w danym roku. Liczba prac z I kwartyla wzrosła (od $26,1 \%$ w 2009 r. do 31,2\% w 2015 r.), a publikacje z czasopism z II kwartyla pozostają na podobnym poziomie jak te z I, jednakże można zaobserwować spadek w 2015 r. Dane te ilustruje wykres 2.

Ponieważ w cytowanym tekście założeń do ustawy o szkolnictwie wyższym była mowa o „lawinowym” wzroście publikacji z wskaźnikiem IF z III i IV kwartyla, postanowiłam zsumować dane o artykułach opublikowanych w czasopismach z I i II 
Wykres 2. Publikacje polskich autorów w SSCI (2009-2015)

w podziale na kwartyle

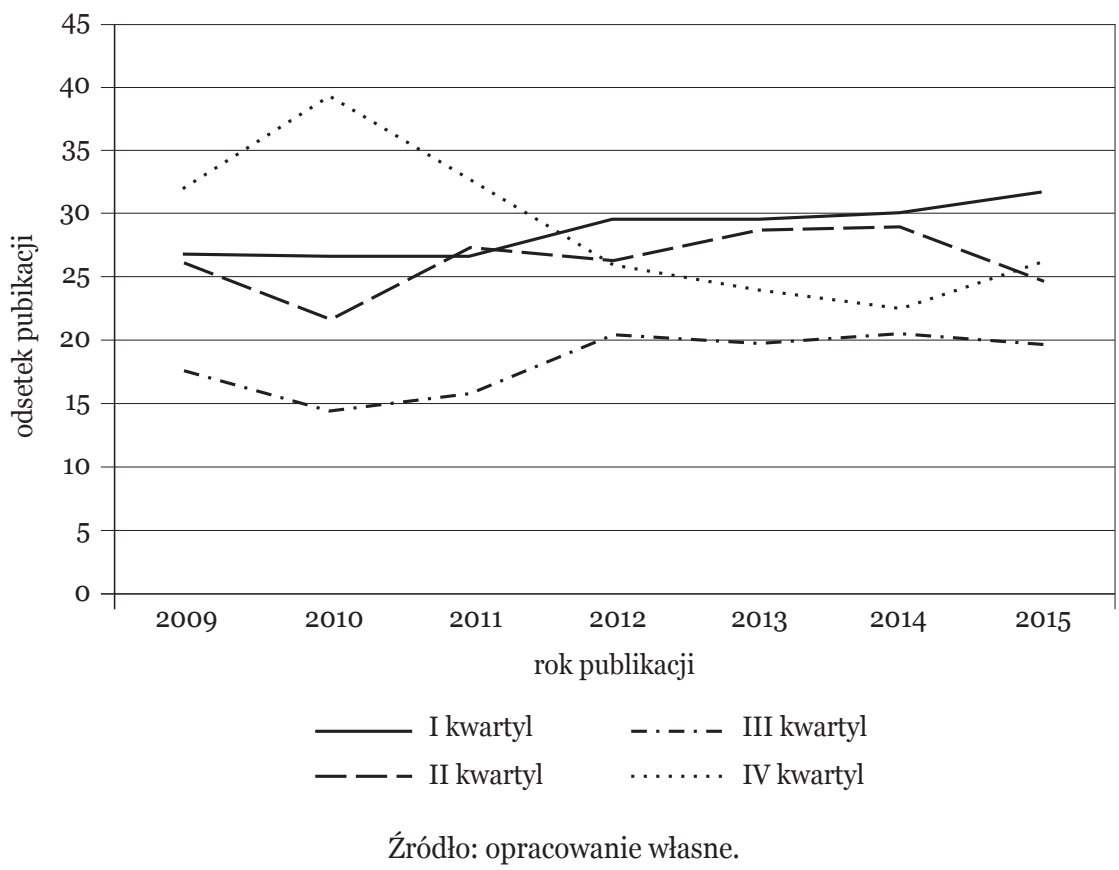

oraz III i IV kwartyla. Kierunek, w jakim zmierzają polscy autorzy, pokazuje wykres 3. Od 2011 r. widać wzrost publikacji z I i II kwartyla (z niewielkim - 2,45\% - spadkiem w 2015 r.) i spadek publikacji z czasopism zaliczonych do III i IV kwartyla z małym wzrostem w 2015 r. Jest to jednocześnie odpowiedź na drugie pytanie badawcze.

Analizując czasopisma, w których publikowali polscy naukowcy w wybranych latach, można zauważyć rosnące zainteresowanie coraz większą liczbą periodyków. W 2009 r. 403 teksty ukazały się w 240 czasopismach. W kolejnych latach obserwujemy stały wzrost aż do 2015 r., kiedy to teksty polskich badaczy z nauk społecznych ukazały się w 744 czasopismach. Dane szczegółowe obrazuje wykres 4.

Jak już wspomniałam, baza danych Social Sciences Citation Index indeksuje niewiele polskich czasopism. Ich liczba wzrosła od trzech (do $2007 \mathrm{r}^{3}$ ) do dziewięciu (w 2008 r.). W latach 2011-2012 trzy czasopisma zostały wyłączone z bazy, a jedno nowe spełniło kryteria indeksowania. W związku z tym od 2012 r. polskie czasopiśmiennictwo z nauk społecznych reprezentuje w SSCI siedem tytułów periodyków.

${ }_{3}^{3}$ Pierwszy Impact Factor wyliczany jest dopiero w trzecim roku indeksacji, więc dla czasopism włączonych do bazy w 2007 r. IF pojawił się w bazie JCR 2009. 
Wykres 3. Odsetek artykułów polskich autorów w SSCI opublikowanych w I lub II kwartylu oraz III i IV kwartylu

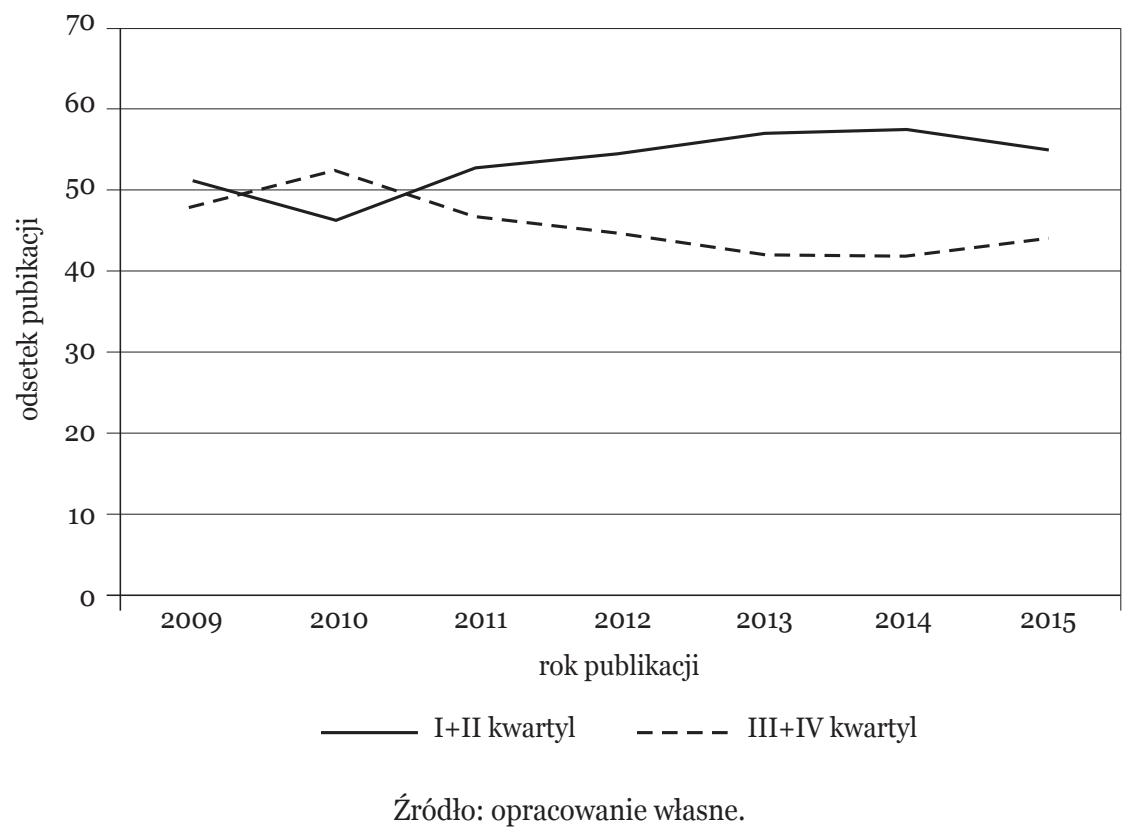

Wykres 4. Liczba czasopism, w których opublikowano artykuły z polską afiliacją

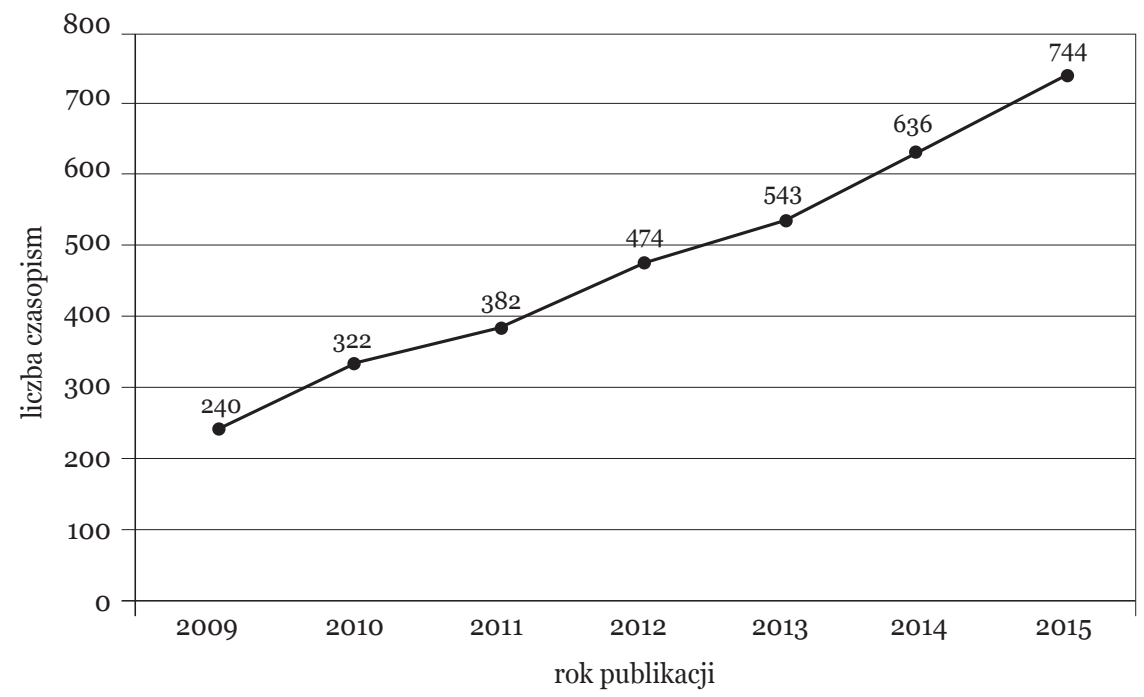

Źródło: opracowanie własne. 
Prace z zakresu nauk społecznych pojawiały się także w innych polskich czasopismach (z nauk ścisłych) i są odnotowywane w tej bazie. Postanowiłam sprawdzić, jaka reprezentacja artykułów z polską afiliacją ukazała się w polskich periodykach.

W latach 2009-2015 artykuły polskich badaczy opublikowane zostały w 23 polskich czasopismach i było to w sumie 808 publikacji, co stanowi $13,2 \%$ wszystkich prac z analizowanego zbioru. Czasopisma z największą liczbą tekstów autorów z polską afiliacją to:

- Polish Sociological Review - 132 artykuły,

- The New Educational Review - 102,

- Problemy Ekorozwoju - 92,

- International Journal of Occupational Safety and Ergonomics - 88,

- Studia Socjologiczne - 75,

- Annals of Agricultural and Environmental Medicine - 63,

- Ekonomista - 60,

- Argumenta Oeconomica - 54,

- Poznan Studies in Contemporary Linguistics - 53.

Najwięcej publikacji w polskich czasopismach ukazało się w latach 2009-2010 i stanowiły one wówczas ok. $25 \%$ prac z danego roku. W ostatnich analizowanych latach (2013-2015) w periodykach z Polski ukazuje się ok. 8\% artykułów z polską afiliacją.

Wykres 5. Artykuły z polską afiliacją

opublikowane w polskich i zagranicznych czasopismach w latach 2009-2015

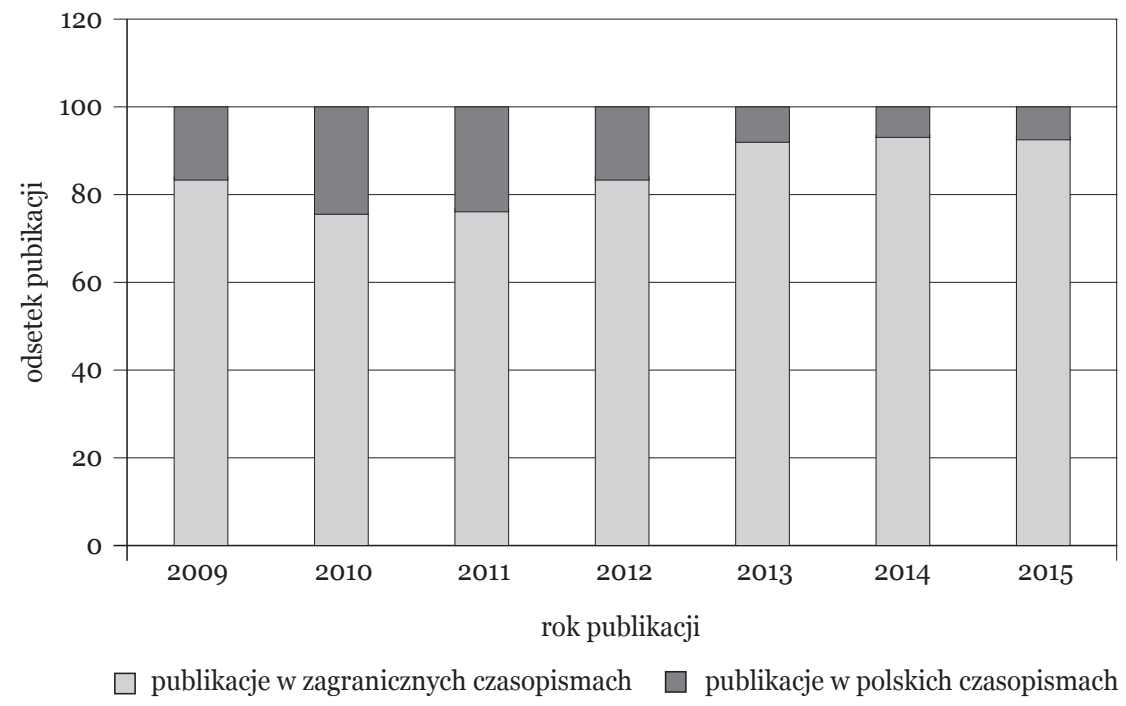

Źródło: opracowanie własne. 
Z tego wynika, że odsetek publikacji przygotowanych przez polskich autorów i opublikowanych w polskich czasopismach z części A „Wykazu czasopism punktowanych" od 2012 r. maleje, a w latach 2014-2015 zmniejszył się trzykrotnie w porównaniu z 2010 czy $2011 \mathrm{r}$.

\section{Podsumowanie}

Analiza danych pokazała, że polscy naukowcy prowadzący badania w zakresie nauk społecznych publikują coraz więcej artykułów w czasopismach indeksowanych w SSCI, dla których był wyliczony wskaźnik IF. W 2015 r. opublikowano ponad 1000 artykułów więcej w porównaniu z 2009 r.

Badacze nie tylko coraz częściej przesyłają wyniki swoich badań do publikacji w czasopismach z SSCI, kierując się wysokością IF oraz plasujące się w coraz wyższym kwartylu IF. Od 2010 r. odsetek artykułów z I i II kwartyla jest wyższy od tych opublikowanych w czasopismach z III i IV kwartyla. W 2014 r. różnica ta była najwyższa i wyniosła $15,7 \%$.

Wyniki te przeczą przytoczonemu na wstępie artykułu twierdzeniu, że mamy do czynienia z lawinowo rosnącą liczbą publikacji z III i IV kwartyla. Dodatkowo sprawdzenie, czy polscy autorzy nie wykorzystują przede wszystkim możliwości publikacji w polskich czasopismach, pokazało, że odsetek artykułów z polską afiliacją w polskich czasopismach maleje od 2010 r., gdy wyniósł ponad 25\%, do poziomu ok. 8\% w latach 2013-2015. Zauważyłam również, że w ciągu siedmiu lat ponad trzykrotnie zwiększyła się liczba periodyków, które przyjęły do publikacji wyniki badań Polaków.

Podsumowując: można zauważyć, że choć publikacje w czasopismach SSCI stanowią wciąż niewielki odsetek wszystkich publikacji z nauk społecznych, polscy naukowcy mają coraz większą świadomość, w jakich czasopismach warto publikować i jakie mogą stąd czerpać korzyści, dlatego coraz częściej wybierają nie tylko „jakiekolwiek" czasopisma z wyliczonym IF, ale te najbardziej prestiżowe, które mają duży wpływ na naukę światową.

\section{Podziękowania}

Bardzo dziękuję Ewie Rozkosz za konstruktywne uwagi i pomoc w analizie danych, a także Emanuelowi Kulczyckiemu i Krystianowi Szadkowskiemu za wszelkie poprawki i sugestie odnośnie do tego artykułu. Publikacja powstała w ramach projektu „Współczesna polska humanistyka wobec wyzwań naukometrii” finansowanego ze środków Narodowego Programu Rozwoju Humanistyki, numer decyzji 0057/NPHR3/H11/82/2014. 


\section{Literatura}

Garfield, E. (2006). The History and Meaning of the Journal Impact Factor. Journal of the American Medical Association. 293: 90-93.

Izdebski, H. (red.) (2017). Propozycja założeń do ustawy regulującej system szkolnictwa wyższego. Warszawa: Uniwersytet SWPS. http://bit.ly/2rhWo3G [6.05.2017].

Kulczycki, E. (2017a). Assessing publications through a bibliometric indicator. The case of comprehensive evaluation of scientific units in Poland. Research Evaluation. 1-12, doi: 10.1093/reseval/rvw023.

Kulczycki, E. (2017b). Punktoza jako strategia w grze parametrycznej w Polsce. Nauka i Szkolnictwo Wyższe. 1(49): 63-78.

Kulczycki, E., Rozkosz, E.A., Drabek, A. (2016). Ocena ekspercka jako trzeci wymiar ewaluacji krajowych czasopism naukowych. Nauka. 1: 107-142.

Kulczycki, E., Drabek, A., Rozkosz, E.A. (2015). Publikacje a zgłoszenia ewaluacyjne, czyli zniekształcony obraz nauki w Polsce. Nauka. 3: 35-58.

Kwiek, M. (red.) (2016). Projekt założeń do ustawy Prawo o szkolnictwie wyższym. Poznań: Uniwersytet im. A. Mickiewicza. http://bit.ly/2pWOS95 [6.05.2017].

Leydesdorff, L. (2012). Alternatives to the journal impact factor: I3 and the top-10\% (or top25\%?) of the most-highly cited papers. Scientometrics. 92(2): 355-365. doi:10.1007/ s11192-012-0660-6.

Radwan, A. (red.) (2017). Plus ratio quam vis consuetudinis: Reforma nauki i akademii w Ustawie 2.o. Projekt założeń do ustawy Prawo o szkolnictwie wyższym. Wyd. 2. Kraków: Oficyna Allerhanda. http://bit.ly/2qvYCtJ [29.04.2017].

Regulamin przyznawania Nagrody im. Prof. Josepha B. Sidowskiego (2014). http://www. kul.pl/files/55/regulamin_nagrody_2_01_2014.pdf [6.05.2017].

Regulamin w sprawie zasad, trybu i kryteriów kwalifikacyjnych przyznawania nagród Rektora nauczycielom akademickim Uniwersytetu Medycznego w Białymstoku (2016). http://bit.ly/2pWJItG [6.05.2017].

Rozporządzenie MNiSW z 12 grudnia 2016 r. (Dz.U. z 27.12.2016 r., poz. 2154) w sprawie przyznawania kategorii naukowej jednostkom naukowym i uczelniom, w których zgodnie z ich statutami nie wyodrębniono podstawowych jednostek organizacyjnych.

Solari, M., Magri, H.-M. (2000). A New Approach to the SCI Journal Citation Reports, a System for Evaluating Scientific Journals. Scientometrics. 47(3): 605-625, doi:10.1023/ A:1005680202961.

Towpik, E. (2015). IF-mania: Journal Impact factor nie jest właściwym wskaźnikiem oceniania wyników badań naukowych, indywidualnych uczonych ani ośrodków badawczych. Nowotwory. Journal of Oncology. 65(6): 465-475, doi:10.5603/NJO.2015.0092.

Zabel, M., Rafajłowicz, E., Dahlig-Turek, E., Hanke, W., Mach, B., Brzeziński, P. (2014). Punktoza, czyli wskaźniki bibliometryczne stosowane przez KEJN w ocenie parametrycznej jednostek naukowych. Forum Akademickie. 9. http://bit.ly/2ridHjD [29.04.2017].

Zarządzenie nr 11 z dnia 2 marca 2016 r. w sprawie grantów naukowych dla nauczycieli akademickich w Szkole Głównej Handlowej w Warszawie. http://bit.ly/2pOrPkM [6.05.2017]. 


\section{Publications of the Polish scientists indexed in the Social Sciences Citation Index in the 2009-2015 period}

ABSTRACT. This article examines publications of the Polish scientists which are indexed in the Social Sciences Citation Index. All the articles and reviews from the 2009-2015 period $(N=6109)$ published in 1,799 journals were analyzed into the study. An impact factor quartile has been assigned to each journal on the basis of the the Journal Citation Reports. The present study has revealed that Polish scientists publish more articles in journals that are indexed on the $A$ list of the Polish Journal Ranking and, at the same time, the share of articles from the first and second impact factors quartiles has been significantly growing.

KEYWORDS: Social Sciences Citation Index, Journal Citation Reports, Impact factor Quartile, parametric evaluation

CYTOWANIE: Drabek, A. (2017). Publikacje polskich naukowców indeksowane w Social Sciences Citation Index w latach 2009-2015. Nauka i Szkolnictwo Wyższe. 1(49): 169-179. doi: 10.14746/ nisw.2017.1.8. 
